Dept. of Poultry Diseases,

Faculty of Vet. Med. Al-Baath University.

\title{
IDENTIFICATION OF DIFFERENT SEROTYPES OF INFECTIOUS BRONCHITIS VIRUSES WITH SINGLE AND MULTIPLEX RT-PCR IN SYRIA
}

(With 2 Tables and One Figure)

\author{
By \\ H.G. ALMUSTAFA and M.M. FADEL
}

(Received at 4/2/2011)

\section{SUMMARY}

Infectious bronchitis virus (IBV) causes respiratory disease in chickens all over the world. (IBV) has many serotypes that do not confer cross protection against each other. The current study was designed to know which IBV types were circulating in Syrian broiler chickens. Tracheal swabs from 9 broiler flocks at the acute phase of respiratory disease were collected. The swabs were subjected to RNA extraction and tested by reverse transcription PCR (RT-PCR). Specific-nested PCR were performed on RT-PCR products to detect and differentiate strains of Massachusetts, (B/793) 4/91, and D274 types. The nucleic acid of IBV was detected in 5 out $9(55.6 \%)$ broiler flocks by RT-PCR. Specific-nested PCR revealed that $44.45,33.35$, and $11.1 \%$ of these flocks had D274, Massachusetts, and 4/91, respectively. In $33.35 \%$ of tested flocks, 2 types of IBV were detected. However, because the primers used in this study were designed specifically for 3 types of IBV, other types might have been present but not detected. Future work should include the isolation and molecular characterization of IBV in the region to adopt a suitable vaccination program using the common field serotypes as vaccines to protect against IBV-caused disease.

Key words: Poultry, infectious bronchitis, PCR, Syria.

\section{INTRODUCTION}

Infectious bronchitis virus (IBV) is a member of the Coronavirdiae family that are enveloped particles containing singlestranded RNA genome of positive polarity. The virus causes a highly contagious respiratory disease in chickens (Williams et al., 1992; Cavanagh et al., 1997). 
Infectious bronchitis (IB) is an acute, highly contagious, viral respiratory disease of chickens, characterized by tracheal rales, coughing, and sneezing. In addition, it may affect the kidneys, and in laying flocks, it decreases egg production and impairs the quality of eggs produced. The disease is common worldwide and has significant economic consequences (Cavanagh, and Naqi, 2003).

Although effective vaccines are available and utilized routinely in commercial poultry production, the virus has the tendency to mutate frequently (Wang et al., 1993). More than 20 serotypes within the IBV are recognized worldwide (Lee and Jackwood 2000). The Massachusetts (Mass)-type was first isolated in Europe in the 1940s (Cavanagh and Davis 1992). The D274-type was the most common serotype in several western European countries in the early and mid-1980s (Cook, 1984; Cavanagh et al., 1992). The 4/91-type was first isolated in 1985 in France; later its type was identified in the United Kingdom (UK) (Cook et al., 1996).

In Syria, the poultry industry comprises broiler breeders, layers, and broilers. Serious respiratory diseases of unknown etiology have been affecting chickens for a number of years, causing economical losses to farmers and poultry companies.

The prevalence and severity of respiratory diseases in commercial chicken flocks has increased recently, due to the intensification of the poultry industry. Infectious bronchitis is of significant economic concern for poultry producers all the worldwide (De Wit, 2000).

This study was reported to detect the IBV by using the reversetranscription polymerase chain reaction and Specific-nested PCR were performed on RT-PCR products to detect and differentiate strains of Massachusetts, (B/793) 4/91, and D274 types which not previously documented in Syria. This commercial chicken was suffering from acute phase of respiratory diseases.

\section{MATERIALS and METHODS}

\section{Broiler Flocks}

During the period from January 2010 to November 2010, we examined 9 commercial broiler flocks from governorates in central Syria in which the chickens were suffering from respiratory disease. Three to Five sterile swabs (Heinz Herenz Medizinalbedarf GmbH, Hamburg, Germany) were taken from 3 - 5 chickens from each flock at the acute phase of respiratory disease and stored at $4{ }^{\circ} \mathrm{C}$ until RNA was extracted. Vaccination history included all flocks vaccinated against the M-41 strain of IBV (Intervet, Wim de Ko“ rverstraat, AN Boxmeer, the Netherlands). In the 
majority of these flocks, signs of respiratory disease usually appeared at 16 to 35 days of age Chickens suffered from severe gasping, coughing, conjunctivitis, nasal and ocular discharge, depression, weakness, and were reluctant to move.

Gross lesions observed in these flocks included a moderate to severe congestion of trachea with or without mucopurelent exudates, airsaculitis, and pericarditis or perihepatitis.

\section{RNA Extraction:}

Swabs from each flock were placed in $1,000 \mu \mathrm{L}$ of PBS (pH 7.2) and were scraped on the side of the tube to facilitate removal of contents from the swab head. Extraction of RNA was performed on $60 \mu \mathrm{L}$ of the pooled material for swab from each flock, using a Pure script RNA purification kit (RNeasy®Plus QIAGEN) according to the procedure of the manufacturer.

\section{RT-PCR and Nested PCR}

The RT-PCR reaction was performed using 2-step RT-PCR, an Access RT-PCR System kit (Sensiscript ${ }^{\circledR}$ Reverse Transcription, QIAGEN), and primers XCE2- and XCE2+ (Alpha DNA, Montreal, Quebec, Canada; Table 1) according to the procedure of the manufacturer. Reverse transcription PCR was carried out in a DNA Engine thermal cycler. For 1 reverse transcription cycle of $60 \mathrm{~min}$ at $45^{\circ} \mathrm{C}$, followed by $94^{\circ} \mathrm{C}$ for $5 \mathrm{~min}$, then $40 \mathrm{PCR}$ cycles of $94^{\circ} \mathrm{C}$ for $45 \mathrm{~s}, 57^{\circ} \mathrm{C}$ for $45 \mathrm{~s}$, and $72^{\circ} \mathrm{C}$ for $90 \mathrm{~s}$, with a final extension cycle at $72^{\circ} \mathrm{C}$ for $5 \mathrm{~min}$.

Table 1: Sequences of oligonucleotide used in reverse transcription PCR (RT-PCR)

\begin{tabular}{|c|c|c|c|c|}
\hline Oligonucleotide & Sequences & Specificity & $\begin{array}{c}\text { Band size } \\
\text { (bp) }\end{array}$ & References \\
\hline XCE2+ & 5'-CACTGGTAATTTTTCAGATGG-3' & Universal & 466 bp & $\begin{array}{c}\text { Adzaher } \\
\text { et al. (1997) }\end{array}$ \\
\hline XCE2- & 5'-CCTCTATAAACACCCTTGCA-3' & & & \\
\hline
\end{tabular}

Nested PCR reaction contained 0.5 of RT-PCR product of positive reactions, $45 \mu \mathrm{L}$ Reddymix (1.1X ReddyMix), and $0.5 \mu \mathrm{L}$ of each of the oligonucleotides MCE1+, DCE1+, and BCE1+ (50 Pmol/ $\mu \mathrm{l}$; Alpha DNA). A total reaction volume of $50 \mu \mathrm{L}$ was obtained by adding nuclease-free water. 
Table 2: Sequences of oligonucleotide used in reverse transcription Nested PCR (RT-PCR)

\begin{tabular}{|c|c|c|c|c|}
\hline Oligonucleotide & Sequences & Specificity & $\begin{array}{c}\text { Band size } \\
\text { (bp) }\end{array}$ & References \\
\hline XCE3- & 5'-CAGATTGCTTACAACCACC-3' & & & $\begin{array}{c}\text { Adzaher } \\
\text { et al. (1997) }\end{array}$ \\
\cline { 1 - 3 } DCE1+ & 5'-TTCCAATTATATCAAACCAGC-3' & D274 & $217 \mathrm{bp}$ & \\
\cline { 1 - 3 } MCE1+ & 5'-AATACTACTTTTACGTTACAC-3' & Mass & $295 \mathrm{bp}$ & $\begin{array}{c}\text { D.A.Roussan } \\
\text { et al. (2008) }\end{array}$ \\
\cline { 1 - 3 } BCE1+ & 5'-AGTAGTTTTGTGTATAAACCA-3' & $4 / 91$ & $154 \mathrm{bp}$ & \multirow{2}{*}{} \\
\hline
\end{tabular}

The nested PCR were performed using the following conditions: $94^{\circ} \mathrm{C}$ for $1 \mathrm{~min}, 48^{\circ} \mathrm{C}$ for $2 \mathrm{~min}$, and $72^{\circ} \mathrm{C}$ for $90 \mathrm{~s}, 35$ cycles followed by a final extension cycle of $72^{\circ} \mathrm{C}$ for $10 \mathrm{~min}$. The IBV (M41) antigen [Gezondheidsdienst voor Dieren B.V. (GD), Animal Health Service Deventer, the Netherlands] was used as a positive control for RNA xtraction and RTPCR. Negative control (nuclease-free water) was also used in each run.

\section{Agarose Gel Electrophoresis}

The RT-PCR and nested PCR products were electrophoresed on a 2\% agarose gel in Tris-acetate-EDTA buffer (Roussan et al., 2008) (40 $\mathrm{mM}$ of Tris and $2 \mathrm{mM}$ of EDTA, with a $\mathrm{pH}$ value of 8.0) containing ethidium bromide (Promega Corp.) for $45 \mathrm{~min}$ at $100 \mathrm{~V}$ and visualized under ultraviolet light (AlphaImager; Alphainnotech, San Leandro, CA).

\section{RESULTS}

All of the tested broiler flocks that were received had a history of respiratory disease. The IBV were detected by RT-PCR in 5 out $9(55.6 \%)$ of these flocks.

Specific-nested PCR were performed on RT-PCR-positive products 5 to detect and differentiate strains of the Massachusetts, 4/91, and D274 types. The results of specific- nested PCR were 44.5, 33.35, and $11.1 \%$ of these flocks had D274, Massachusetts, and 4/91, respectively. On the other hand, 33.35 of these flocks were infected with both Massachusetts + D274. 
The overall results of specific-nested PCR indicated the IBV D274 and Massachusetts types were found to be most prevalent, whereas the IBV 4/91 type was found to be of low prevalence (11.1\%). Figure 1 shows RTPCR and nested PCR for IBV detection and subtyping (Massachusetts, 4/91, and D274).

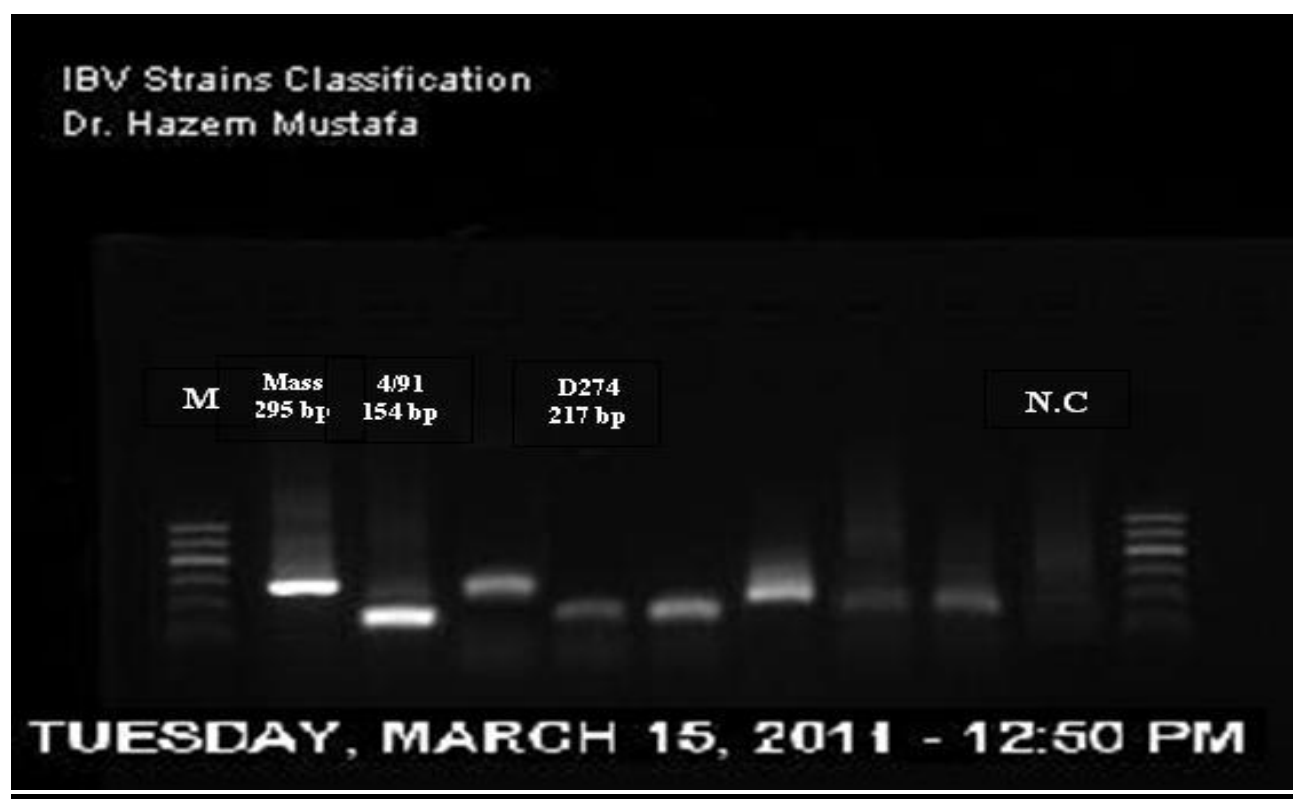

Figure 1: Shows Nested RT-PCR

\section{DISCUSSION}

Current diagnosis of IB is commonly based on virus isolation in embryonating eggs, followed by immunological identification of the isolates. This procedure is time consuming and requires the use of specific polyclonal or monoclonal antibodies.

Moreover, some isolates could be mixtures of different types of IBV that can confuse the interpretation of serotyping results. Reverse transcription PCR has been described previously using IBV, RNA extracted from tracheal swabs.

These techniques had been shown to be very efficient for the detection of IBV and for the identification of IBV types (Cavanagh et al., 1999; Handberg et al., 1999). In this study, we performed RT-PCR on the tracheal swabs from birds with a history of respiratory disease. Furthermore, the RT-PCR-positive reactions were subjected to specificnested PCR to detect and differentiate strains of the Massachusetts, 
4/91, and D274 types. The IBV had been detected in 55.6\% of broiler flocks by RT-PCR. Nested PCR results indicated that the main IBV types circulating in the Syrian broiler population were the D274 type and, Massachusetts type which represent 44.45 and $33.35 \%$, respectively, followed by $4 / 91$, which represents $11.1 \%$ of tested flocks.

However, because the primers were selected specifically for these 3 types of IBV, other types might have been present but not detected. Massachusetts-type IBV was detected in $33.35 \%$ of the broilers tested. In a recent study, (Cavanagh et al., 1999) reported that when Massachusettstype IB vaccines were applied at $1 \mathrm{~d}$ old in the hatchery, vaccine virus could later be detected in all broiler flocks tested by RT-PCR on swabs, with maximal amounts during the first week of life.

In our work, most of the Massachusetts type detected was from broilers showing respiratory signs beyond 2-3 wk of age.

Our results suggest field exposure of these flocks to Massachusetts type alone or in combination with other type of IBV.

Thirty Three $(33.35 \%)$ of tested flocks were infected with 2 types of IBV. This is in agreement with previous observations showing that broiler flocks may be infected simultaneously with several types of IBV (Cavanagh et al., 1999). The results in a current study indicate a relatively high prevalence of 2 types of IBV (i.e., D274 and Massachusetts types), in addition to a low prevalence of the 4/91 type. This study and suggested that there is a possibility of the presence of several IBV stains in Syrian.

Like in many other parts of the world, (Cavanagh, and Naqi, 2003) Massachusettstype vaccines are the only officially authorized vaccines in Syrian. Despite the use of these IBV vaccines, it is common to find IB problems in vaccinated chickens.

The results of this study may partially explain the failure of Massachusetts-type vaccines and necessitate revising the Syrian vaccination program against IB. In this study, the sequence of PCR products was not determined, and therefore the origin of the isolates is not clear at present.

In conclusion, by utilizing such diagnostic techniques, it is possible to conduct a detailed epidemiological study to determine the full economic effect of this disease. Future work should include the isolation, serotyping, and molecular characterization of IBV in the region to adopt a suitable vaccination program using the common field serotypes as vaccines to protect against IBV-caused disease. 


\section{REFERENCES}

Adzhar, A.; Gough, R.E.; Haydon, D.; Shaw, K.; Britton, P. and Cavanagh, D.(1997): Molecular analysis of the 793/B serotype of infectious bronchitis virus in Great Britain. Avian Pathol. 26: 625-640.

Boltz, DA.; Nakai, M. and Bahra, JM. (2004): Avian infectious bronchitis virus: a possible cause of reduced fertility in the rooster. Avian Dis. 48 (4): 909-15.

Cavanagh, D. and Davis, PJ. (1992): Sequence analysis of strains of avian infectious bronchitis coronavirus isolated during the 1960s in UK. Arch. Virol. 130: 471-476.

Cavanagh, D. and Naqi, S. (2003): Infectious bronchitis, in diseases of poultry, Y.M. Saif. H.J. Barnes, J.R. Glisson, A. M. Fadly, L.R. Mcdougald, and D.E. Swayne (eds). Ames, Iowa: Iowa State University Press pp. 101-119.

Cavanagh, D.; Davis, PJ.; Cook, JKA.; Li, D.; Kant, A. and Koch, G. (1992): Location of the amino-acid differences in the S1 spike glycoprotein subunit of closely related serotypes of infectious bronchitis virus. Avian Pathol .21: 33-43.

Cavanagh, D.; Elus, MM. and Cook, JK. (1997): Relationship between sequence variation in the $\mathrm{S} 1$ spike protein of infectious bronchitis virus and the extent of cross-protection in vivo. Avian Pathol. 26(1): 63-74.

Cavanagh, D.; Mawditt, K.; Britton, P. and Naylor, C.J. (1999): Longitudinal field studies of infectious bronchitis virus and avian pneumovirus in broilers using type-specific polymerase chain reactions. Avian Pathol. 28: 593-605.

Cook, JKA. (1984): The classification of new serotypes of infectious bronchitis virus isolated from poultry flocks in Great Britian between 1981 and 1983. Avian Pathol. 13: 733-741.

Cook, JKA.; Orbell, SJ.; Woods, MA. and Huggins, MB. (1996): A survey of the presence of a new infectious bronchitis virus designated 4/91(793/B). Vet Res.138: 178-180.

De Wit, JJ. (2000): Detection of infectious bronchitis virus. Avian Pathol. 29: 71-93.

Handberg, K.J.; Nielsen, O.L.; Pedersen, M.W. and Jorgensen, P.H. (1999): Detection and strain differentiation of infectious bronchitis virus in tracheal tissues from experimentally infected chickens by reverse transcription polymerase chain reaction. 
Comparison with an immunohistochemical technique. Avian Pathol. 28: 327-335.

Lee CW. and Jackwood, MW. (2000): Evidence of genetic diversity generated by recombination among avian coronavirus IBV. Arch. Virol. 145: 2135-2148.

Roussan, D.A.; Totanji, W.S. and Khawaldeh, G.Y. (2008): Molecular subtype of infectious bronchitis virus in broiler flocks in Jordan. Poultry Science 87: 661-664.

Wang, L.; Junker, D. and Gollisson, EW. (1993): Evidence of natural recombination within the $\mathrm{S} 1$ gene of infectious bronchitis virus. Virology 192: 710-716.

Williams, AK.; Wang, L.; Sneed, LW. and Collisson, EW. (1992): Comparative analyses of the nucleocapsid genes of several strains of infectious bronchitis virus and other coronaviruses. Virus Res. 25 (3): 213-22. 